\title{
STANDARDIZATION PARAMETERS OF MODIFIED EXTRACTS FROM LEONURUS CARDIACA HERB
}

\author{
(C) Ye. Romanenko, O. Koshovyi, T. Ilyina, N. Borodina, N. Melnyk
}

\begin{abstract}
На сьогодні в Украӥні зареєстровано 8 комбінованих лікарських засоби кропиви собачої, настойку випускають 10 вітчизняних підприємств, фасовану сировину - 3 вітчизняні заводи. Настойка собачої кропиви має певні недоліки: непостійність хімічного складу, і відповідно, фармакодинаміки; містить етиловий спирт, тому протипоказана дітям, вагітним, особам, діяльність яких потребує підвищеної уваги тощо. У зв'язку з иим, розробка стандартизованих лікарських засобів на основі настойки трави собачої кропиви, яка б не містила в своєму складі етанол, є актуальним завданням.

Мета. Визначити параметри стандартизаиії модифікованого сухого екстракту з настойки собачої кропиви та розробити проект методик контролю якості на ичю субстанцію.

Методи дослідження. Об'єктом дослідження був сухий екстракт на основі собачої кропиви настойки (Виробник: ОАО «Лубнифарм», серія 062021), який був модифікований з лізином. Для аналізу використовували три серії екстрактів.

При визначенні параметрів стандартизаиї̈ одержаного сухого екстракту собачої кропиви трави використовували стандартні фармакопейні методики. За основу розробки методик контролю якості на сухий екстракт собачої кропиви були взяті монографії ДФУ «Собачої кропиви трава», «Собачої кропиви настойка» та «Лізину гідрохлорид».
\end{abstract}

Результати дослідження. Визначено параметри стандартизаиії модифікованого сухого екстракту собачої кропиви трави. Запропоновано контролювати якість одержаного екстракту за такими показниками: описом, розчинністю, ідентифікувати екстракт методом ТШХ за вмістом флавоноїдів, іридоїдів та лізину, втратою в масі при висушуванні, залишковою кількістю органічних розчинників (етанолу), мікробіологічною чистотою, вмістом важких металів, кількісну стандартизацію проводити за вмістом флавоноїдів (не менше $2 \%$ ) та іридоїдів (не менше 0,5\%).

Проаналізовано три серії екстракту згідно запропонованого проекту МКЯ, які повністю відповідали йому за всіма показниками.

Висновки. Визначено параметри стандартизаиії модифікованого сухого екстракту з настойки собачої кропиви, який був одержаний з використанням лізину, та розроблено проект методик контролю якості на ию субстанцію. Проаналізовано три серії екстракту згідно запропонованого проекту МКЯ, які повністю відповідали йому за всіма показниками.

Ключові слова: собача кропива, трава, настойка, модифікаиія, лізин, сухий екстракт, біологічно активні речовини, параметри, стандартизачія.

\section{Introduction}

Modern life in conditions of chronic stress and emotional overload leads to the appearance of symptoms of neurogenic and psychosomatic diseases. According to the results of modern studies, from 60 to $90 \%$ of visits to the doctor are associated with stressful conditions. When choosing sedatives, more than $80 \%$ of the population prefer pharma drugs. This is due to a number of reasons, including a comprehensive action aimed at various aspects of disease development, a high safety and effectiveness profile, as well as relative cheapness and accessibility $[1,2]$.

Herb of Leonurus cardiaca - one of the most used medicinal herbs with sedative action. The most commonly used medicinal product on the basis of this medicinal plant is the tincture of Leonurus cardiaca. Demand also includes combination drugs and functional supplements, which include biologically active substances (BAS) of Leonurus cardiaca. To date, in Ukraine there are 8 combination of herbal medicines with Leonurus cardiaca, 10 domestic enterprises produce tincture, 3 domestic enterprises pack Leonurus cardiaca [1, 3-5].
The main biologically active substances (BAS) of the Leonurus cardiaca are derivatives of flavone (apigenin) [6, 7], flavonol (quercetin, campferol), quinqueloside, quercetin-7-glucoside, hyperoside, rutin, genququinine, quercitin, 5,4'-dihydroxy -7-methoxy flavone, kosmosian, 4-rutinoside of carboxylic acid [8, 9]. Detected tannins (about 2-5\%), triterpene saponins (ursolic acid), steroid glycosides [10, 11], traces of essential oils (about $0.03 \%$ ): cariofilin, $\alpha$-humumulin, $\alpha$ pinene, $\beta$-pinene, limonene, linalool; resin present, iridoid such as aucubin (ayugol, azhogoside, galyridoside) and diterpenes (leocardin and marubin) $[12,13]$.

2. Formulation of the problem in a general way, the relevance of the theme and its connection with important scientific and practical issues

It should be noted that the tincture of Leonurus cardiaca has certain disadvantages: the incidence of chemical composition, and, accordingly, pharmacodynamics; contains ethyl alcohol, therefore it is contraindicated for children, pregnant women, persons whose activities require increased attention, etc. Ethanol is not a 
pharmacologically indifferent substance, there is a dangerous possibility of potentiation of certain drugs by ethanol $[1,14,15]$.

In this regard, the development of standardized drugs based on the tincture of herb of Leonurus cardiaca, which would not contain ethanol in its composition, is an urgent task.

\section{Analysis of recent studies and publications in} which a solution of the problem and which draws on the author

Previously, in the works [16, 17], the technology of obtaining dry tincture of Leonurus cardiaca grass was substantiated, the essence of technology, which consists in replacing the alcohol with a dry excipient (sucrose, mannitol, sorbitol, etc.). The obtained product is characterized by advantageous technological parameters: satisfactory bulk properties, less hygroscopicity and stability during storage.

Amino acids in extracts can form salts and complexes with other BAS groups, for example, with phenolic compounds, which alter their physico-chemical properties, affect solubility and bioavailability, total pharmacological effect. Modification of galenic drugs by various amino acids leads to an increase in their activity and the emergence of new pharmacological effects [18, 19]. Therefore, the modification of tincture of Leonurus cardiaca with the help of amino acids and standardization of new dry extracts is an actual task of modern pharmacy $[20,21]$.

\section{Allocation of unsolved parts of the general problem, which is dedicated to the article \\ Having analyzed the current state of the research of medicinal products based on tincture of Leonurus cardiaca, it is advisable to determine the parameters of standardization of the previously obtained modified dried extract from this raw material, which showed the most pronounced sedative activity $[22,23]$.}

\section{Formulation of goals (tasks) of Article}

Determine the standardization parameters of the modified dry extract from Leonurus cardiaca tincture in accordance with the requirements of the SPHU and develop a draft quality control methodology for this substance.

\section{Statement of the basic material of the study (methods and objects) with the justification of the results}

The object of the study was dry extract based on the Leonurus cardiaca tincture (Manufacturer: OAO "Lubnifarm", series 062021), modified with lysine. For analysis, three series of extracts were used.

In determining the parameters of standardization of the obtained dry extract of Leonurus cardiaca herbs used standard pharmacopoeial techniques. The basis of the development of quality control methods for dry ex- tract of dog nettles was taken monographs SPHU "Leonurus cardiaca grass", "Leonurus cardiaca tincture" and "Lysine hydrochloride" [23-25].

The extract must be obtained from raw material that meets the requirements described in the monographs "Leonurus cardiaca grass" or "Leonurus cardiaca tincture" depending on the original product.

Description. The Leonurus cardiaca extract dry makes a dry mass of lightweight brown light, bitter to taste with a faint odor.

Solubility. To determine further technological manipulations with the extract and the direction of its use, it was necessary to determine its solubility. The extract is readily soluble in $50 \%$ ethyl alcohol, moderately soluble in $96 \%$ ethyl alcohol and water, dissolves very little in chloroform and ether. Tests were conducted in accordance with the requirements of the SPHU 1.4.

Identification. Since the standardization of the primary raw material (tincture, Leonurus cardiaca herb) controls the content of flavonoids, it is advisable to control the content of these substances in the resulting dry extract (method A) [23, 25]. Studies on the relationship between the chemical composition of extracts from Leonurus cardiaca herbs and their pharmacological activity have shown that significant contribution to the sedative effect of these agents is iridoid, which is very labile substances, therefore they should also be determined in dry extracts (method B) [26, 27]. Since the modification of Leonurus cardiaca tincture is carried out using lysine, it is also advisable to determine its presence (method C) [24].

Identification of the major BAS groups in the extracts was carried out using thin-layer chromatography (2.2.27).

Method A. Identification of the main substances of flavonoid nature [13, 23].

Test solution. $1 \mathrm{~g}$ of dry extract was dissolved in $10 \mathrm{ml}$ of $96 \%$ ethanol or methanol, filtered through a paper filter, evaporated off the solvent and dissolved in 1 $\mathrm{ml}$ of methanol.

Comparison solution. $5 \mathrm{mg}$ of hyperoside $P$ and $5 \mathrm{mg}$ of routine $P$ are dissolved in $5 \mathrm{ml}$ of methanol $R$.

Plate: TLC plate with a layer of silica gel $\mathrm{R}$

Moving phase: acetic acid $P$ - water $P$ - ethyl acetate $P$ (20:20:60).

Volume of the sample to be applied: $30 \mu \mathrm{l}$, with stripes. Distance that must pass a moving phase: $10 \mathrm{~cm}$ from the start line.

Drying: in the air.

Detection: sprayed with a solution of dimethylaminobenzaldehyde P2, using $5 \mathrm{ml}$ per plate in an area of $200 \mathrm{~mm}^{2}$; is heated at a temperature from $100{ }^{\circ} \mathrm{C}$ to $105{ }^{\circ} \mathrm{C}$ for 10 minutes prior to the occurrence of stains; viewed in daylight.

Results: The sequence of zones on the chromatograms of the test solution and the solution of the comparison is given. On the chromatogram of the test solution, other zones can also be detected (Fig. 1). 


\begin{tabular}{|l|l|}
\hline \multicolumn{2}{|c|}{ The upper part of the plate } \\
\hline Hyperoside: yellowish-brown zone & Intense zone of yellowish-brown (hyperoside) \\
\hline Rutin: yellowish-brown zone & Intense zone of yellowish-brown \\
\hline & The area is from a grayish-blue to grayish-green color \\
\hline & $\begin{array}{l}\text { Areas of different intensity from grayish-blue to bright } \\
\text { blue (iridoid) }\end{array}$ \\
\hline Solution of the comparison & Test solution \\
\hline
\end{tabular}

Fig. 1. Diagram of chromatogram of dry extract of Leonurus cardiaca herb

Method B. Identification of basic substances of iridoid nature [28, 29].

About $5 \mathrm{~g}$ of dry extract (precise weight) are placed in a $100 \mathrm{ml}$ round bottom flask, $50 \mathrm{ml}$ of $40 \%$ ethyl alcohol are heated and heated to a boiling water bath with reflux for 45 minutes. The extract is cooled and filtered through a cotton swab into a $100 \mathrm{ml}$ volumetric flask. The solution is brought to the mark with $40 \%$ ethyl alcohol (Solution A).

$10 \mathrm{ml}$ of the resulting solution is evaporated to $5 \mathrm{ml}$. Transfer quantitatively the resulting solution to a $10 \mathrm{ml}$ volumetric flask, bring the volume of solution to the mark with water, and filter through a glass column of $1 \mathrm{~cm}$ in diameter with $3 \mathrm{~g}$ of aluminum oxide of the second degree of activity.

On a chromatographic plate, $0.05 \mathrm{ml}$ of the resulting solution is applied. Chromatograph by ascending method in the solvent system chloroform $\mathrm{P}$ - methanol $\mathrm{P}$ - water $\mathrm{P}$ (80: 2: 0.1 ). After separation, the plate is removed and dried in air until the solvent is removed. Develop the plate with Stahl reagent (1.0 g of $\mathrm{p}$ dimethylaminobenzaldehyde dissolved in a mixture of $50 \mathrm{ml}$ of acetic acid, $5 \mathrm{ml}$ of phosphorus acid and $100 \mathrm{ml}$ of water). The solution is suitable for 7 days.

At least 3 zones of violet-purple color with $\mathrm{Rf}$ of about $0.40 \pm 0.05$ (harpagoside), a spot with Rf of about $0.6 \pm 0.05$ (ayugoside), a spot with Rf of about 0.8 should appear on the chromatogram \pm 0.05 (harpagoside acetate).

Method C. Identification of lysine (2.2.27) [24].

Test solution. $1 \mathrm{~g}$ of dry extract was dissolved in $10 \mathrm{ml}$ of $96 \%$ ethanol or methanol, filtered through a paper filter, evaporated off the solvent and dissolved in $1 \mathrm{ml}$ of methanol.

Comparison solution. $10 \mathrm{mg}$ of RS lysine hydrochloride is dissolved in water $\mathrm{R}$ and the volume of the solution is adjusted to $50 \mathrm{ml}$ with the same solvent.

Plate: TLC plate with a layer of silica gel $R$.

Moving phase: ammonia concentrated P-2propanol $P$ (30:70).

On the starting line of the chromatographic plate, $5 \mu \mathrm{l}$ of the test solution and $5 \mu \mathrm{l}$ of the comparison solution are applied. The plate is dried in air and placed in a chamber with a mixture of solvents. When the solvent front is $15 \mathrm{~cm}$ from the start line, the plate is removed from the chamber, dried at a temperature of $100{ }^{\circ} \mathrm{C}$ to $105^{\circ} \mathrm{C}$ until ammonia odor disappears and sprayed with a solution of ninhydrin $\mathrm{R}$. The plate is heated at a temperature of $100{ }^{\circ} \mathrm{C}$ to $105^{\circ} \mathrm{C}$ for $15 \mathrm{~min}$. The chromato- gram of the test solution reveals the main intensive zone at the level of the spot on the chromatogram of the comparison solution.

Test.

Loss in mass during drying. Not more than $10.0 \%$. The definitions are carried out according to SPHU 2.0 (2.8.17). $0.50 \mathrm{~g}$ of ground powdered extract of the powder is placed in a batch and dried in a drying cabinet at a temperature of $100{ }^{\circ} \mathrm{C}$ to $105^{\circ} \mathrm{C}$ for 3 hours. $\mathrm{Cool}$ in a desiccator and weigh.

Residual amounts of organic solvents (ethyl alcohol).

The content of alcohol in the extract of Leonurus cardiaca should not exceed $1.0 \%$

Approximately $1 \mathrm{~g}$ (exact weighting) of the extract is introduced into a $10 \mathrm{ml}$ volumetric flask, dissolved in $7 \mathrm{ml}$ of water, add $1 \mathrm{ml}$ of acetone and 1,2dichloroethane (internal standards), bring the volume of solution to the mark with water, and mix.

$1 \mu \mathrm{l}$ of the resulting solution and solution of the reference sample (RS) of ethyl alcohol are chromatographed on a gas chromatograph with a flame-ionization detector, yielding not less than 5 chromatograms.

The results of the analysis are considered reliable if the requirements of the test "Checking the suitability of the chromatographic system" are met.

Heavy metals. For the purpose of toxicological safety in all types of phytochemical products it is necessary to control the content of heavy metals, according to the requirements of the SPHU (2.4.8) their content should not be more than $100 \mathrm{ppm}$.

Microbiological purity. For phytochemical agents microbial contamination is characteristic, therefore, it is necessary to control the amount of viable bacteria and fungi in the extract. Tests are carried out in accordance with the requirements of the SPHU, 2.6.12, 2.6.13

To determine the total number of viable aerobic bacteria, $10 \mathrm{~g}$ of the extract is placed in a sterile measuring vessel, adjusted to $500 \mathrm{ml}$ with a sterile neutralizing liquid containing $10 \%$ polysorbate-80 and $20 \%$ isopropyl myristate. For $1 \mathrm{ml}$ of the prepared sample, they are sown using a two-layered method on each of five Petri dishes with a dense nutrient medium No. 1.

To determine the total number of viable mushrooms, $10 \mathrm{~g}$ of the drug is placed in a sterile measuring vessel, brought to a $500 \mathrm{ml}$ sterile neutralizing liquid 
containing $10 \%$ polysorbate- 80 and $20 \%$ isopropyl

myristate. $1 \mathrm{ml}$ of the prepared sample was sown in a two-layered method on each of five Petri dishes with a dense medium No. 2.

To test for the presence of enterobacteria and some other gram-negative bacteria, Pseudomonas aeruginosa and Staphylococcus aureus, $10 \mathrm{~g}$ of the drug is placed in a sterile measuring vessel, adjusted to $500 \mathrm{ml}$ sterile neutralizing liquid containing $10 \%$ polysorbate80 and $20 \%$ isopropyl myristate. For $50 \mathrm{ml}$ of the prepared sample, add $500 \mathrm{ml}$ of nutrient medium No. 3 and No. 8.

The standardization of the microbiological purity of the extract is established in accordance with the requirements of the SPHU, 5.1.4, category 2.

The preparation allows the total number of viable aerobic microorganisms: no more than 100 microorganisms (bacteria and fungi in total) in $1 \mathrm{~g}$.

The presence of enterobacteria and some other gram-negative bacteria in $1 \mathrm{~g}$ is not allowed. The presence of Pseudomonas aeruginosa in $1 \mathrm{~g}$ is not allowed. The presence of Staphylococcus aureus in $1 \mathrm{~g}$ is not allowed.

Composition of neutralizing liquid containing $10 \%$ polysorbate- 80 and $20 \%$ isopropyl myristate: polysorbate $80-100 \mathrm{~g}$, isopropyl myristate $-200 \mathrm{~g}$, lecithin (egg) $-3 \mathrm{~g}$, histidine hydrochloride $-1 \mathrm{~g}$, peptone enzymatic $-1 \mathrm{~g}$, sodium chloride $-4.3 \mathrm{~g}$, potassium dihydrogen phosphate - $3.6 \mathrm{~g}$, disodium hydrophosphate dihydrate $-7.2 \mathrm{~g}$, purified water $-1000 \mathrm{ml}$.

Quantitative determination. The content of flavonoids in the extract of Leonurus cardiaca was determined by the spectrophotometric method in terms of the hyperoside for SPHU 2.2.25. The content must be at least $2 \%$ in terms of hyperoside and dry substance.

Initial solution. $1.0 \mathrm{~g}$ (exact weight) of dry extract is placed in a flask of $50 \mathrm{ml}$ capacity, dissolved in $70 \%$ ethyl alcohol, filtered through a paper filter, and the filtrate is evaporated in a water bath to an almost dry residue. To the resulting residue, add 0.5 $\mathrm{ml}$ of a solution of $5 \mathrm{~g} / \mathrm{L}$ of hexamethylenetetramine $\mathrm{P}, 15 \mathrm{ml}$ of acetone $\mathrm{P}, 1 \mathrm{ml}$ of hydrochloric acid P1, and add the flask to the reflux condenser and boil for $30 \mathrm{~min}$. After cooling, the contents of the flask are filtered through a paper filter in a volumetric flask of $50 \mathrm{ml}$ capacity, a $100 \mathrm{ml}$ flask is washed with $15 \mathrm{ml}$ of acetone $\mathrm{P}$, the washing liquid is filtered through the same filter in the same measuring flask, the volume of the solution is adjusted with acetone $\mathrm{P}$ to $50.0 \mathrm{ml}$, rinsing flask and paper filter, and mix.

$20.0 \mathrm{ml}$ of the resulting solution are placed in a separating funnel, $20 \mathrm{ml}$ of water $\mathrm{R}$ is added and the mixture is shaken with $15 \mathrm{ml}$ of ethyl acetate $\mathrm{P}$, and then with 3 portions, each of $10 \mathrm{ml}$ each, of ethyl acetate R. The ethyl acetate extracts obtained are combined in a divider funnel, washed in 2 portions, each $50 \mathrm{ml}$ each, water $\mathrm{R}$, filter over $10 \mathrm{~g}$ sodium anhydrous sulfate $\mathrm{P}$ into a volumetric flask and bring the volume of solution with ethyl acetate $\mathrm{P}$ to $50.0 \mathrm{ml}$.
Test solution. To $10.0 \mathrm{ml}$ of the stock solution, add $1 \mathrm{ml}$ of the aluminum chloride $\mathrm{R}$ reagent and adjust the volume of the solution with $5 \%(\mathrm{v} / \mathrm{v})$ acetic acid $\mathrm{P}$ acid in methanol $\mathrm{P}$ to $25.0 \mathrm{ml}$.

Compensation solution. $10.0 \mathrm{ml}$ of the stock solution is adjusted with a solution of $5 \%(\mathrm{v} / \mathrm{v})$ of aceticacidic $\mathrm{P}$ acid in methanol $\mathrm{P}$ to a volume of $25.0 \mathrm{ml}$.

Measure the optical density (2.2.25) of the test solution after 30 minutes in relation to the compensation solution at $425 \mathrm{~nm}$ wavelength.

The content of the amount of flavonoids, in terms of hyperoside, in percentages, is calculated by the formula:

$$
\frac{A \times 0,625}{m},
$$

where $\mathrm{A}$ is the optical density of the test solution at a wavelength of $425 \mathrm{~nm}, \mathrm{~m}$ - weight of weight loss of dry extract of Leonurus cardiaca, in $\mathrm{g}$.

They use a specific index of absorption of hyperoside equal to 500 .

The content of iridoids in the extract of Leonurus cardiaca was determined by the spectrophotometric method in terms of harpagoside acetate. The content should be not less than $0.5 \%$ in terms of garnet acetate and air-dry substance $[29,30]$.

$10 \mathrm{ml}$ of the resulting solution A (from the identification stage of the iridoid compounds) are evaporated to $5 \mathrm{ml}$. Transfer the resulting solution quantitatively into a volumetric flask of $10 \mathrm{ml}$ capacity and bring the volume of solution to the mark with water. Filter through a glass column $1 \mathrm{~cm}$ in diameter with $3 \mathrm{~g}$ of aluminum oxide of the II degree of activity.

Into a volumetric flask of $25 \mathrm{ml}$, place $5 \mathrm{ml}$ of eluate, add $5 \mathrm{ml}$ of alkaline solution of hydroxylamine and stand for 5 minutes. Then add $10 \mathrm{ml}$ of $1 \mathrm{M}$ hydrochloric acid solution, add $1 \%$ iron chloride solution (III) in a 0.1 $\mathrm{M}$ solution of hydrochloric acid to the label and mix.

The optical density of the resulting solution is measured on a spectrophotometer at a wavelength of $512 \mathrm{~nm}$. As a comparison solution, use a mixture made in a $25 \mathrm{ml}$ volumetric flask: add $10 \mathrm{ml}$ of a $1 \mathrm{M}$ solution of hydrochloric acid to $5 \mathrm{ml}$ of a hydroxylamine solution and bring to the mark with $1 \%$ iron chloride solution (III) in a $0.1 \mathrm{M}$ solution of hydrochloric acid.

The content of iridoids in the extract in terms of harpagoside acetate $(\mathrm{X})$ was calculated by the formula:

$$
X=\frac{A * 25 * 100 * 100 * 100}{56 * m * 5(100-w)}
$$

where A - optical density of the investigated solution;

56 - specific indicator of absorption of standard garpagide acetate immediately; $\mathrm{m}$ is the weight of the extract, $\mathrm{g}$; $\mathrm{w}$ is the moisture content of the extract, $\%$.

The results of analysis of samples of herbs extracts according to the developed quality control methodology project are given in Table 1. 
Table 1

Results of analysis of Leonurus cardiaca herb dry extract according to the MQC project

\begin{tabular}{|c|c|c|c|c|}
\hline \multirow[t]{2}{*}{ Quality indicators } & \multirow[t]{2}{*}{ Permissible limits } & \multicolumn{3}{|c|}{$\begin{array}{l}\begin{array}{l}\text { Results of determination in extracts, } \\
\text { series }\end{array} \\
\end{array}$} \\
\hline & & 1 & 2 & 3 \\
\hline Description & $\begin{array}{l}\text { Amorphous hygroscopic powder from light } \\
\text { brown to brown, bitter to taste with a faint odor. }\end{array}$ & + & + & + \\
\hline \multicolumn{5}{|l|}{ Solubility } \\
\hline$-96 \%$ ethanol & moderately soluble & + & + & + \\
\hline$-50 \%$ ethanol & easily soluble & + & + & + \\
\hline - ether & very little soluble & + & + & + \\
\hline - chloroform & very little soluble & + & + & + \\
\hline - water & moderately soluble & + & + & + \\
\hline \multicolumn{5}{|c|}{ Identification } \\
\hline $\begin{array}{l}\text { Identification of fla- } \\
\text { vonoids }\end{array}$ & Method A (TLC). According to MQC project & + & + & + \\
\hline $\begin{array}{l}\text { Identification of iri- } \\
\text { doids }\end{array}$ & Method B (TLC). According to MQC project & + & + & + \\
\hline Identification of lysine & Method C (TLC). According to MQC project & + & + & + \\
\hline \multicolumn{5}{|c|}{ Tests } \\
\hline $\begin{array}{l}\text { Loss in mass during } \\
\text { drying }\end{array}$ & Not more than $10 \%$ & $6.9 \pm 0.2$ & $5.1 \pm 0.3$ & $4.5 \pm 0.1$ \\
\hline $\begin{array}{l}\text { Residual amounts of } \\
\text { organic solvents: - } \\
\text { ethanol }\end{array}$ & Not more than $1,0 \%$ & 0.4 & 0.3 & 0.2 \\
\hline Heavy metals & Not more than $100 \mathrm{ppm}$ & + & + & + \\
\hline Microbiological purity & $\begin{array}{l}\text { In } 1 \mathrm{~g} \text { of the drug no more than } 100 \text { microorgan- } \\
\text { isms (bacteria and fungi in total). The presence } \\
\text { of enterobacteria and some other gram-negative } \\
\text { bacteria in } 1 \mathrm{~g} \text { is not allowed. Presence of Pseu- } \\
\text { domonas aeruginosa in } 1 \mathrm{~g} \text { is not allowed. Pres- } \\
\text { ence of Staphylococcus aureus in } 1 \mathrm{~g} \text { is not al- } \\
\text { lowed. }\end{array}$ & + & + & + \\
\hline \multicolumn{5}{|c|}{ Quantitative determination } \\
\hline $\begin{array}{l}\text { The content of flavo- } \\
\text { noids }\end{array}$ & not less than $2 \%$, in terms of hyperoside & $2.11 \pm 0.02$ & $2.34 \pm 0.05$ & $2.22 \pm 0.03$ \\
\hline $\begin{array}{l}\text { The content of iri- } \\
\text { doids }\end{array}$ & $\begin{array}{c}\text { not less than } 0,5 \% \text { in terms of harpagoside ace- } \\
\text { tate }\end{array}$ & $0.67 \pm 0.04$ & $0.59 \pm 0.02$ & $0.81 \pm 0.01$ \\
\hline
\end{tabular}

Note. "+»-extract meets the requirements of the $M Q C$

According to the analysis, it can be concluded that all series of Leonurus cardiaca herbs extract dry meet the requirements of the developed MQC project.

7. Conclusions from the conducted research and prospects for further development of this field

The parameters of standardization of modified dried extract of tincture of Leonurus cardiaca, which was obtained using lysine, were determined, and a draft quality control methodology was developed for this substance. Three series of extract were analyzed in accordance with the proposed MQC project, which fully met all the indicators.

The resulting standardized extract will be used to design new dosage forms of medicinal products with sedative effect.

\section{References}

1. Mashkovskiy M. D. Lekarstvennye sredstva. Moscow: OOO «Izd-vo Novaya Volna», 2010. 1216 p.

2. Wojtyniak K., Szymański M., Matlawska I. Leonurus cardiacaL. (Motherwort): A Review of its Phytochemistry and Pharmacology // Phytotherapy Research. 2012. Vol. 27, Issue 8. P. 1115-1120. doi: http://doi.org/10.1002/ptr.4850

3. Vyvchennia khimichnoho skladu ta psykhotropnoi aktyvnosti sukhoho ekstraktu travy kropyvy sobachoi / Romanenko Ye. A. et. al. // Liky - liudyni. Kharkiv: NFaU, 2017. Vol. 2. P. 274.

4. Popescu M. L., Dinu M., Toth O. Contributions to the pharmacognostical and phytobiological study on Leonurus cardiaca L. (Lamiaceae) // Farmacia. 2009. Vol. 57, Issue 4. P. 424-431.

5. Variation in the Composition of the Essential Oil of CommercialValeriana officinalisL. Roots from Different Countries / Raal A. et. al. // Journal of Essential Oil Research. 2008. Vol. 20, Issue 6. P. 524-529. doi: http://doi.org/10.1080/10412905.2008.9700079 
6. The study of the chemical composition of the components of the motherwort herb / Romanenko Y. A. et. al. // News of Pharmacy. 2018. Vol. 3, Issue 95. P. 34-38. doi: http://doi.org/10.24959/nphj.18.2222

7. New Labdane Diterpenes fromLeonurus cardiaca / Agnihotri V. et. al. // Planta Medica. 2008. Vol. 74, Issue 10. P. 12881290. doi: http://doi.org/10.1055/s-2008-1081304

8. The comparison of anti-oxidative kinetics in vitro of the fluid extract from maidenhair tree, motherwortand hawthorn / Bernatoniene J. et. al. // Acta Poloniae Pharmaceutica Drug Research. 2009. Vol. 66, Issue 4. P. 415-421.

9. Luo Y., Luo S., Zhou B. Chromatographic identification of a compound similar to ferulic acid in the decoction of Herb Leonuri // Zhong Yao Cai. 2002. Vol. 25, Issue 10. P. 713-714.

10. Ursolic acid: a potent Inhibitor of superoxides produced in the cellular system / Ali M. S. et. al. // Phytotherapy Research. 2007. Vol. 21, Issue 6. P. 558-561. doi: http://doi.org/10.1002/ptr.2108

11. Leonurus cardiaca L. Herb-a derived extract and an ursolic acid as the factors affecting the adhesion capacity of Staphylococcus aureus in the context of infective endocarditis / Micota B. et. al. // Acta Biochimica Polonica. 2014. Vol. 61, Issue 2. P. 74-82. doi: http://doi.org/10.18388/abp.2014_1911

12. Fitokhimichne vyvchennia ridkoho ekstraktu travy kropyvy sobachoi ta doslidzhennia yoho psykhotropnoi aktyvnosti / Romanenko Ye. A. et. al. // Zbirnyk naukovykh prats spivrobitnykiv NMAPO imeni P. L. Shupyka. 2015. Issue 24 (5). P. $212-217$.

13. Kuchta K., Volk R. B., Rauwald H. W. Stachydrine in Leonurus cardiaca, Leonurus japonicus, Leonotis leonurus: detection and quantification by instrumental HPTLC and 1H-qNMR analyses // Pharmazie. 2013. Vol. 68, Issue 7. P. 534-540.

14. Ovanesov K. B., Ovanesova I. M., Arushanian E. B. Effects of melatonin and motherwort tincture on the emotional state and visual functions in anxious subjects // Eksp. Klin. Farmakol. 2006. Vol. 69, Issue 6. P. 17-19.

15. The study of a new dry extract of the motherwort herb: abst. of 9th Intern. Pharm. Conf. / Romanenko Ye. et. al. // Science and practice 2018. Kaunas, 2018. P. 38.

16. Dotsilnist stvorennia ta rozrobka tekhnolohii novoi likarskoi formy roslynnykh preparativ - sukha nastoika / Dmytriievska I. D. et. al. // Ukrainskyi zhurnal klinichnoi ta laboratornoi medytsyny. 2011. Vol. 6, Issue 2. P. 4-8.

17. Likuvalno profilaktychnyi zasib z sedatyvnoiu diieiu: Pat. No. 97049 UA. MPK: A61K 36/533, A61K 9/14, A61K 47/26, A61P 25/20 / Dmytrievska I. D., Danylov S. A., Komisarenko A. M., Dmytriievskyi D. I., Shtryhol S. Y. No. a 2010 13223; declareted: 08.11.2010; published: 26.12.2011; Bul. No. 24. 4 p.

18. Perspektyvy stvorennia novoho hipohlikemichnoho likarskoho zasobu na osnovi biolohichno aktyvnykh rechovyn lystia chornytsi zvychainoi / Kolychev I. O. et. al. // Farmakom. 2016. Issue 1. P. 67-73.

19. Phytochemical study of the dry extract from bilberry leaves / Koshovyi O. M. et. al. // Azerbaijan Pharmaceutical and Pharmacotherapy Journal. 2016. Vol. 16, Issue 1. P. 18-23.

20. Koshovyi O. M. Suchasni pidkhody do stvorennia likarskykh zasobiv na osnovi roslyn rodiv Evkalipt ta Shavliia: Diss.of Doctor of Pharmacy Sciences. Kharkiv, 2013. 246 p.

21. Kotova E. E., Kotov A. H. Systematyzatsiia farmakopeinykh vymoh do metodiv kontroliu yakosti likarskoi roslynnoi syrovyny. Unifikovani spektrofotometrychni metodyky // Farmakom. 2014. Issue 4. P. 22-34.

22. Pytannia vvedennia do DFU natsionalnoi monohrafii «Chornytsi pahony» / Kotova E. E. et. al. // Farmakom. 2016. Issue 3. P. 9-15.

23. Derzhavna Farmakopeia Ukrainy. Vol. 3. Kharkiv: Derzhavne pidpryiemstvo «Ukrainskyi naukovyi farmakopeinyi tsentr yakosti likarskykh zasobiv», 2014. $732 \mathrm{p}$.

24. Derzhavna Farmakopeia Ukrainy. Vol. 1. Kharkiv: Derzhavne pidpryiemstvo «Ukrainskyi naukovyi farmakopeinyi tsentr yakosti likarskykh zasobiv», 2015. 1128 p.

25. Study of dynamic of extraction BAS from motherwort herb for obtaining the tincture / Romanenko Y. A. et. al. // Ukrainian biopharmaceutical journal. 2018. Issue 3 (56). P. 66-71. doi: http://doi.org/10.24959/ubphj.18.185

26. Study of the relations between the main BAS groups content in Leonurus cardiaca tincture and its psychotropic activity / Romanenko Y. et. al. // Ukrainian biopharmaceutical journal. 2018. Issue 4 (57). P. 69-74. doi: http://doi.org/10.24959/ubphj.18.199

27. Kuchta K., Ortwein J., Rauwald H. W. Leonurus japonicus, Leonurus cardiaca, Leonotis leonurus: a novel HPLC study on the occurrence and content of the pharmacologically active guanidino derivative leonurine // Pharmazie. 2012. Vol. 67, Issue 12. P. 973-979.

28. Variation in the composition of the essential oil of Valeriana officinalis L. roots from Estonia. Proceedings of the Estonian / Raal A. et. al. // Proceedings of the Estonian Academy of Sciences. Chemistry. 2007. Vol. 56, Issue 2. P. 67-74.

29. Standartizatsiya lekarstvennykh form na osnove rastitel'nogo syr'ya kornevishh c kornyami valeriany, travi pustyrnika $\mathrm{i}$ plodov boyaryshnika / Khishova O. M. et. al. // Khimiko-farmatsevticheskiy zhurnal. 2004. Vol. 32, Issue 2. P. 37-40.

30. Izuchenie ekstraktsii iridoidnykh glikozidov travy pustyrnika razlichnymi rastvoritelyami / Kosman V. M. et. al. // Khimiko-farmatsevticheskiy zhurnal. 2002. Vol. 36, Issue 2. P. 43-45.

Дата надходження рукопису 15.01.2019

Yevhen Romanenko, Postgraduate student, Department of Pharmacognosy, National University of Pharmacy, Pushkinska str., 53, Kharkiv, Ukraine, 61002

E-mail: gnosy@nuph.edu.ua

Oleh Koshovyi, Doctor of Pharmaceutical Sciences, Professor, Head of Department, Department of Pharmacognosy, National University of Pharmacy, Pushkinska str., 53, Kharkiv, Ukraine, 61002

E-mail: oleh.koshovyi@gmail.com

Tetyana Ilyina, Doctor of Pharmaceutical Sciences, Professor, Department of Pharmacognosy, National University of Pharmacy, Pushkinska str., 53, Kharkiv, Ukraine, 61002

E-mail: ilyinatany86@gmail.com 
Natalia Borodina, $\mathrm{PhD}$, Associate Professor, Department of Pharmacognosy, National University of Pharmacy, Pushkinska str., 53, Kharkiv, Ukraine, 61002

E-mail: natalijaborodina@gmail.com

Natalia Melnyk, National University of Pharmacy, Pushkinska str., 53, Kharkiv, Ukraine, 61002

E-mail: melniknataly97@gmail.com

UDC 615.014.2:615.453

DOI: 10.15587/2519-4852.2019.158002

\section{STUDY OF MEDICAL KITS FROM PASSENGER TRAINS}

\section{(c) R. Sahaidak-Nikitiuk, V. Borodina, N. Demchenko}

Мета. Метою статті є дослідження складу аптечки медичної, якою повинні бути укомплектовані потяги.

Матеріали та методи. У дослідженні застосовувалися такі методи, як контент-аналіз, аналітичний, порівняльний та логічний, експертних опитувань. У прочесі дослідження застосовувалося експертне анкетування, 6 якому брали участь начальники потягів та проводники, загальною кількістю 453 особи. В опитуванні задіяні фахівиі регіональних філій Укрзалізниці, а саме Львівської, Південно-Західної, Південної, Одеської, Приднепровської залізниць. Висновки респондентів є обгрунованими та збіжними, щзо підтверджено коефіцієнтом конкордації та критерісм Пірсону з урахуванням числа свободи, які перевищують нормативні (табличні) значення. Контент-аналіз використовувався для дослідження нормативної бази стосовно укомплектування потягів аптечками медичними.

Результати. Проведене анкетне опитування визначило, ще всі респонденти впевнені в необхідності наявності в потязі аптечки медичної, але значна частина респондентів не знають про ї̈ наявність та місце розташування в потязі. 75,70 \% респондентів вважають, щчо в потязі повинні бути в наявності два види аптечок медичних - у начальника потягу та у провідника. Лише 53,70 \% респондентів відомий склад аптечки медичної, при иььому їх значна частина вважають за необхідне удосконалення складу аптечки та регулярного проходження відповідних курсів надання першої домедичної допомоги та отримання сертифікатів.

На підставі контент-аналіз визначено, щзо пасажирський вагон повинен бути оснащений однією медичною аптечкою та однією додатковою аптечкою на потяг на випадок аварії. При укомплектуванні аптечок медичних рекомендовано оріснтуватися аптечки медичні автомобільні.

Досліджено аптечки медичні, якими укомплектовані потяги Росіі, Республіки Казахстан та Республіки Біларусь.

Висновки. Досліджено склад аптечок медичних, якими укомплектовані потяги України, Росї, Республіки Казахстан та Республіки Біларусь. Визначені переваги та недоліки ичих аптечок та запропоновано напрямки удосконалення аптечок медичних, якими укомплектовані потяги Укралізниці

Ключові слова: аптечка медччна, поїз, аварія, залізниця, начальник поӥзда, пострадавщте, лікарський засіб, виріб медичного призначення, провідник, долікарська допомога

\section{Introduction}

One of the problems that is worrying around the world is the continued increase in rail accidents, as their consequences are quite significant, both in terms of irreversible human and material losses and time losses.

The largest accidents involving trains include the accident at a railway in Denmark, which killed eight people [1]. In the Netherlands, a bicycle with four children was lost to the train, and two adults were traumatized [2]. In Serbia, a train and a bus collided, leaving five people dead, 30 injured, and more than 10 people in severe condition are in the hospital [3]. In Ukraine, the passenger train № 139 Kyiv-Kamyanets-Podilsky collided with a maneuvering locomotive, resulting in the first train of the train descended from the rails, hospitalized four children and one adult [4].

2. Formulation of the problem in a general way, the relevance of the theme and its connection with important scientific and practical issues

In Ukraine, the number of traffic accidents on the railways is gradually decreasing, but the number of injured as a result of these accidents increases. Thus, during 2018, there were 79 accidents on the railroad, in which 16 people died and 30 [5] injured. During the corresponding period in 2017 there were 86 accidents, the number of deaths was 20, injured - 22 [6] (Fig. 1). 